\title{
Design and construction of a prototype bongo to carry out rescue maneuvers as an instruction aid in the Diving and Salvage School of the Colombian Navy.
}

Diseño y construcción de un prototipo de un bongo para realizar maniobras de salvamento como ayuda a la instrucción en la Escuela de Buceo y Salvamento de la Armada Nacional de Colombia.

DOI: https://doi.org/10.25043/19098642.193

Daniel Villamizar Mantilla ${ }^{1}$
John Gómez Morales ${ }^{2}$
Wilson Ovalle Porras ${ }^{3}$
Lissette Casadiego

\section{Abstract}

The diving and salvage school of the Colombian Navy offers training in rescue maneuvers, with the purpose that students acquire the skills and abilities required for effective surveillance, protection and attention of people and materials at sea that may involve dangerous situations or threaten human life. Therefore, the teaching and learning skills of student divers have to be improved.

The purpose of the project is to design and build a bongo that will allow the students to effectively observe the applicability of the fundamentals of physics such as: Archimedes' principle, Boyle's law and Pascal's principle, as a theoretical and practical tool that serves as effective training on rescue maneuvers in real time for students and under controlled conditions at the facilities of the Diving School of the Navy in the city of Cartagena. For its execution, exploratory research was carried out and a deductive method was applied, which began with the planning study and shipbuilding method used by COTECMAR, followed by the analysis and use of materials as a result of the experience of the Naval Base BN1 "ARC BOLIVAR" in this type of constructions. Construction manuals for rescue equipment of the United States Navy were also used as references. The existing BONGO ARC "CASA", was used as reference and its information served as an input for naval architecture calculations and finally allowed the construction of the Bongo with the technical specifications required for training in this area of knowledge. The device was put into service for the Diving and Salvage School as a learning tool, maintaining proportional and aesthetic characteristics that provide ease, comfort, safety and efficiency during the instruction and decision-making process at a low cost and minimizing the risk of accidents.

Key words: Bongo, training, Boyle’s law, Archimedes' principle, Pascal's principle, rescue, simulator.

\section{Resumen}

La Escuela de Buceo y Salvamento de la Armada Nacional de Colombia ofrece capacitación en maniobras de salvamento, con el propósito que los alumnos adquieran las competencias y habilidades necesarias para la efectiva vigilancia, protección y atención de las personas y el material en el mar que pueden caer en situaciones de peligro o amenacen la vida humana, motivo por el cual se evidencia la necesidad de fortalecer las capacidades de enseńanza y aprendizaje a los buzos de la institucional que allí se presentan como alumnos.

El proyecto tiene como objetivo el diseńo y construcción de un bongo que le permita al alumno observar realmente la aplicabilidad de los fundamentos de la física tales como: el principio de Arquímedes, la ley de Boyle y el principio de Pascal, igualmente, el proyecto será una herramienta teórico practica que le sirve al Alumno como entrenamiento eficaz en las maniobras de salvamento en tiempo real y bajo condiciones controladas dentro de las instalaciones de la Escuela de Buceo de la Armada Nacional en la ciudad de Cartagena; Para su ejecución se realizó una investigación exploratoria y de método deductivo, que inició con el estudio de la planeación y método de construcción naval empleado por COTECMAR, seguido del análisis y empleo de materiales producto de la experiencia de la Base Naval BN1 " ARC BOLIVAR" en este tipo de construcciones, también se usaron como referencias los manuales de construcción para equipos de salvamento de la Armada de los Estados Unidos y la comparación con el Bongo ARC "CASA", información que sirvió de insumo para los cálculos de arquitectura naval y que finalmente permitieron la construcción del bongo con las especificaciones técnicas requeridas para la capacitación en este área de conocimiento, dispositivo que fue puesto en servicio para la Escuela de Buceo y Salvamento como herramienta de aprendizaje, manteniendo características proporcionales y estéticas que generan facilidad, comodidad, seguridad y eficacia en los procesos de instrucción y toma de decisiones a bajo costo y minimizando el riesgo de accidentalidad.

Palabras claves: Bongo, entrenamiento, ley de Boyle, principio de Arquímedes, principio de Pascal, salvamento, simulador.

Date Received: April $23^{\text {rd }} 2019$ - Fecha de recepción: Abril 23 de 2019

Date Accepted: September $4^{\text {th }} 2019$ - Fecha de aceptación: Septiembre 4 de 2019

\footnotetext{
${ }^{1}$ Escuela de Buceo y Salvamento. Colombia. Email: daniel.villamizar@armada.mil.co.

${ }^{2}$ Escuela de Buceo y Salvamento. Colombia. Email: john.gomez@armada.mil.co

${ }^{3}$ Jefatura de Formación, Instrucción y Educación Naval. Colombia. Email: wilson.ovalle@armada.mil.co

${ }^{4}$ Escuela Naval de Suboficiales "ARC Barranquilla”. Colombia. Email: lissette.casadiego@armada.mil.co
} 


\section{Introduction}

This research work focuses on strengthening salvage instructions at the Diving and Salvage School, which is intended to be achieved through the construction of a prototype that will serve as a bongo simulator, with the purpose of analyzing and consider the variables of refloating maneuvers and air systems of work platforms, recreating reality during academic training in order to optimize the performance of divers in all areas of the navy.

Now, the fact that this project is carried out through the diving equipment research line provides a space for the explanation and actual application of physics fundamentals such as: Archimedes' principle, Boyle's law and Pascal's principle in the occupational role of divers, thus contributing to the training on physics and salvaging.

In the first place, the theoretical foundation of salvage maneuvers will be explained. Next, the strengthening of the instruction process will be described. Later, the results obtained in the construction of the simulator will be considered and several real examples will be analyzed. Finally, methodological training strategies will be analyzed and recommendations based on the cases analyzed and work methodologies currently used in this type of work platforms will be proposed.

It is necessary to clarify two fundamental concepts: a salvage maneuver is defined as any act or activity carried out at sea to aid a seagoing vessel, its cargo or freight (or to an aircraft at sea) that is danger; and a refloat maneuver is a salvage maneuver that consists in removing water from a compartment or storehouse using compressed air by means of a mechanical source, either a compressor or air bottles, in order to release the water encapsulated in said compartments and thus gain positive buoyancy and go afloat.

\section{Methodology}

The type of research under which this project is developed according to its objective or depth is exploratory and deductive, because there is not enough bibliography about the object of study, which purpose is the construction of a prototype bongo to be used as a simulator in salvage maneuvers, contributing as a tool to strengthen the training of the Diving and Salvage School. This type of research allows the execution of the project to be structured from the review of bibliographic information of the physical theories that support the refloating maneuvers. Likewise, it allows taking into account the opinion of experts in the subject, and therefore the participant observations of researchers, thus becoming the ideal type of research to compare the knowledge theoretically acquired with real experiences in the field.

The research method proposed is deductive because it allows researchers to infer an observed result from a general law, in this case inferences are drawn from the different laws of physics applied to this project, such as: Archimedes' principle, Boyle's law and Pascal's principle, which is why, apart from the observation, the demonstrations of these theories in the operation of the prototype bongo will be used as a research tool.

\section{Results and Discussion}

The fulfillment of the general objective through the following three steps can be considered as a result

\section{Step 1: DESIGN THE MODEL OF THE PROTOTYPE BONGO}

The analysis of the purpose of study begins with the visit to COTECMAR Design and Engineering Management, located at the Mamonal Plant, where the respective approaches were carried out with the personnel trained in the design of smaller and larger vessels. The planning process began there, analyzing all the necessary aspects to be taken into account before construction such as: type of vessel, construction material, budget and all the issues that may be necessary to carry out projects of this size. It is paramount to emphasize that said planning includes the study of all variables that may ensure that vessels have a safe, economical and adequate design or maritime or naval structure. 
Visits were made to the facilities of the COTECMAR plant in BN1 where our project was also made known to the Manager of the Bocagrande Plant of COTECMAR, which is in charge of managing repair and maintenance projects for the Colombian Navy, and contributed with the identification of the specific characteristics of the most suitable materials, both in terms of costs and availability in the local market, in order to choose the materials that best suit our needs and budget in an accurate manner.

Likewise, the salvage manual of the US NAVY was used as reference, with which it was possible to demonstrate how the different salvaging maneuvers are carried out, the majority of which are carried out by refloating with compressed air since it is the most effective and efficient way to achieve it, and therefore would be the method to be implemented in the operation of the prototype bongo.

On the other hand, the measures of the Bongo ARC "CASA" were reviewed in order to have a floating structure as a reference for the construction of our prototype, based on the measures of the naval artifact which are 32.06 meters in length and 9.10 meters of beam; therefore, when dividing the length by the beam, it is evident that the ratio is 3.52 . This information allowed defining a rectangular structure that would meet the conditions that are actually consistent with the original bongo.

Fig. 1. DARPA Suboff main lines.

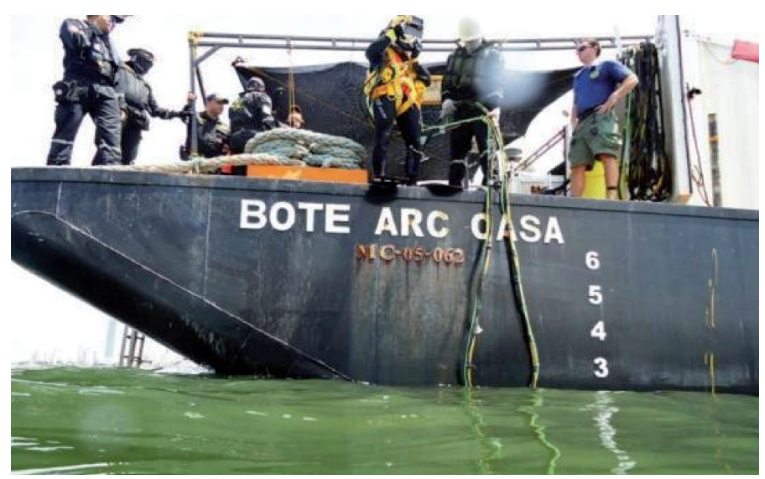

Source: https://www.caracol.com.co/emisora/2017/10/24/ cartagena

Subsequently, the location and capacity of the watertight compartments was observed based on the location and distribution in the Bongo ARC "CASA" in order to determine the location of salvage valves with their respective couplings; in order to design the model establishing the dimensions and weight that will facilitate maneuvering in different scenarios such as the pool of the Naval Base ARC "Bolivar" and the dock of the Salvage Diving Department.

Calculations were made to select the material based on the size previously determined and according to the variables of density, plate thickness, length, width, height, weight and external volume, in order to find the pushing force and determine buoyancy.

Table 1. Pushing force calculations.

\begin{tabular}{|c|c|c|}
\hline \multicolumn{3}{|c|}{ INPUT DATA FOR PROTOTYPE } \\
\hline Length & 2.44 & $\mathrm{~m}$ \\
\hline Beam & 0.8 & $\mathrm{~m}$ \\
\hline Height & 0.47 & $\mathrm{~m}$ \\
\hline Stainless steel density & 7980 & $\mathrm{~kg} / \mathrm{m}^{3}$ \\
\hline Plate thickness & 0.002 & $\mathrm{~cm}$ \\
\hline Sea Water density & 1027 & $\mathrm{~kg} / \mathrm{m}^{3}$ \\
\hline Gravity & 9.8 & $\mathrm{~m} / \mathrm{s}^{2}$ \\
\hline \multicolumn{3}{|c|}{ DATA OF EACH COMPARTMENT } \\
\hline Length & 0.77 & 0.77 \\
\hline Width & 0.35 & 0.35 \\
\hline Height & 0.47 & 0.47 \\
\hline Square area & 0.329 & 0.329 \\
\hline Rectangle area & 0.7238 & 0.7238 \\
\hline Total area & 1.0528 & 1.0528 \\
\hline Compartment Volume & 0.15291 & 0.15291 \\
\hline \multicolumn{3}{|c|}{ CALCULATIONS OF THE PROTOTYPE } \\
\hline Bongo mass & 165.2 & $\mathrm{~kg}$ \\
\hline Square area & 3.008 & $\mathrm{~m}^{2}$ \\
\hline Rectangle area 1 & 3.904 & $\mathrm{~m}^{2}$ \\
\hline Rectangle area 2 & 3.44 & $\mathrm{~m}^{2}$ \\
\hline Total area & 10.35 & $\mathrm{~m}^{2}$ \\
\hline Material volume & 0.021 & $\mathrm{~m}^{3}$ \\
\hline Bongo volume & 0.917 & $\mathrm{~m}^{3}$ \\
\hline Bongo weight & 1619 & $\mathrm{~N}$ \\
\hline Pushing force & 9234 & $\mathrm{~N}$ \\
\hline Buoyancy reserve & 7614 & $\mathrm{~N}$ \\
\hline Maximum load & 777 & $\mathrm{Kg}$ \\
\hline Draft displacement & 0.082 & $\mathrm{~m}$ \\
\hline
\end{tabular}

Source: Authors. 


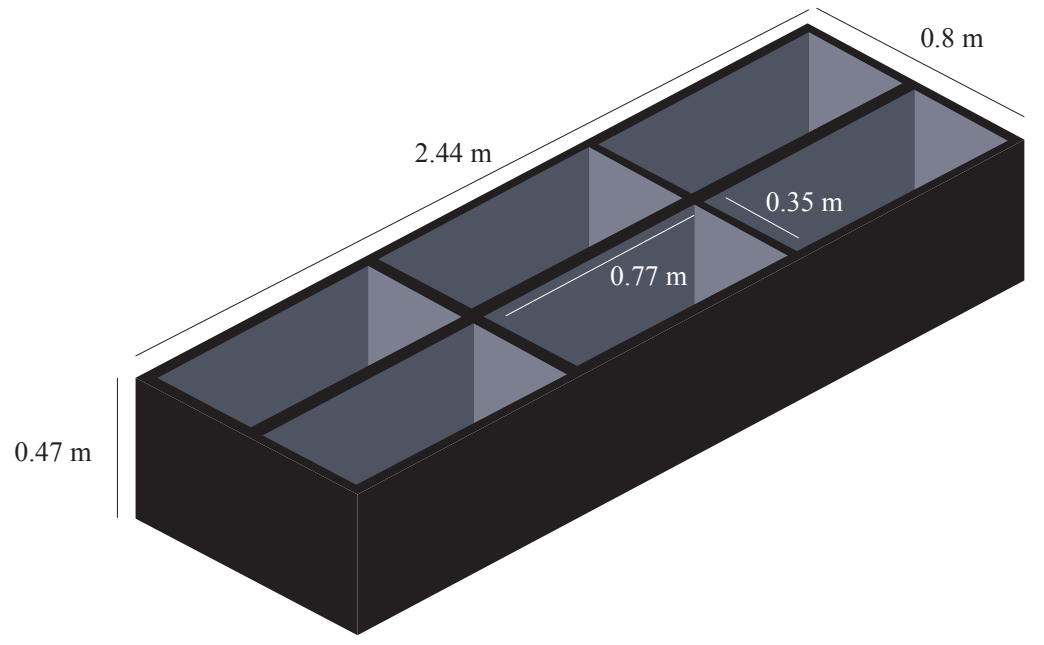

An exercise was carried out that allowed determining the useful life of the bongo in the water and the preservation of its basic operating conditions.

These calculations allowed determining that the structure must be made of stainless steel, with the following measures: length 2.44 meters, beam 0.8 meters, plate thickness 0.2 centimeters, material density $7980 \mathrm{~kg} / \mathrm{m}^{3}$; thus ensuring its viability by demonstrating positive buoyancy.

Considering that the oxygen in water or air attacks iron, it has been determined to work with stainless steel to avoid any steel rust, providing greater stability and high resistance to the corrosion produced by seawater and its prolonged use in salt water, which factors allowed considering it as a better option over other metals.

\section{Step 2: BUILD THE PROTOTYPE BONGO}

Once the materials and tools were determined, a plan was drawn, as observed in Fig. 2, where the design and dimensions are shown, minimizing any errors in the actual construction.

Based on this model, the construction of the prototype was commenced, cutting and welding in the upper part of the structure, organizing the internal system of the bongo, opening holes in the lower plate in order to weld the couplings where water outlet valves are screwed into, see Fig. 3 .

Fig. 3. Cutting and welding to fix check valve couplings.
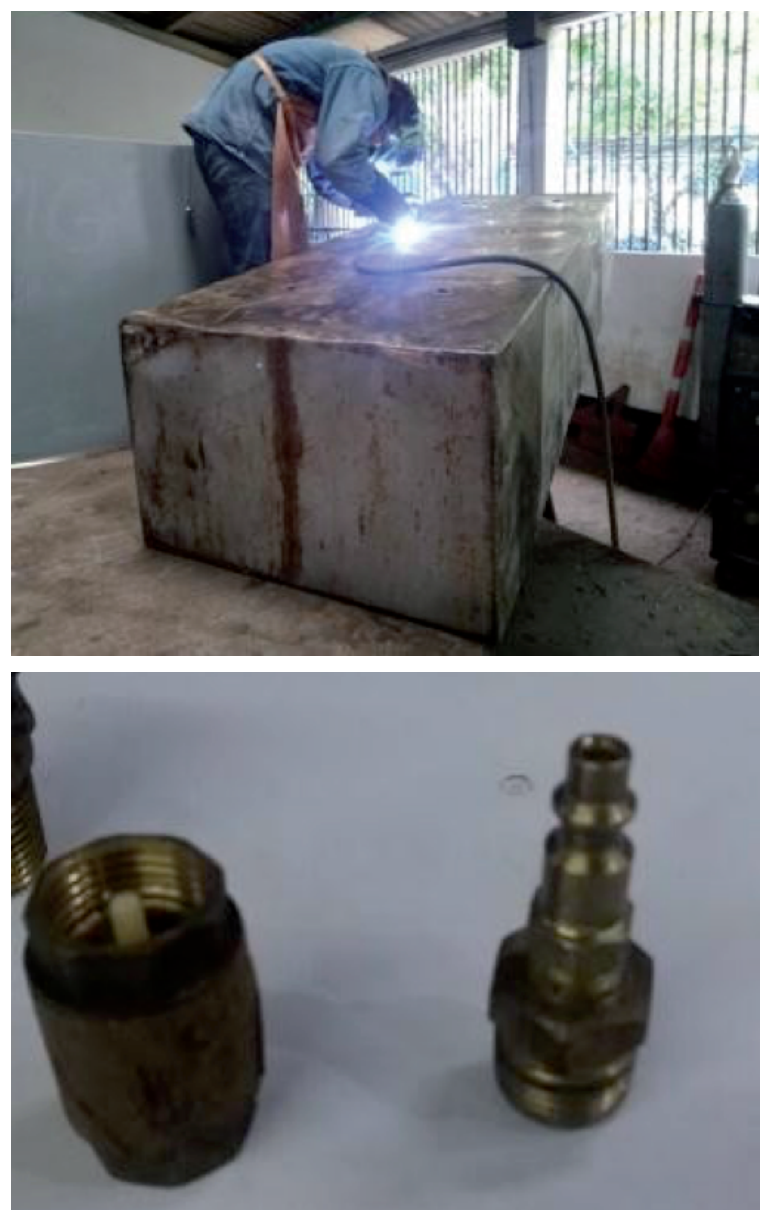

Source: Authors. 
Fig. 4. Application of fiberglass on the inside of the Prototype.

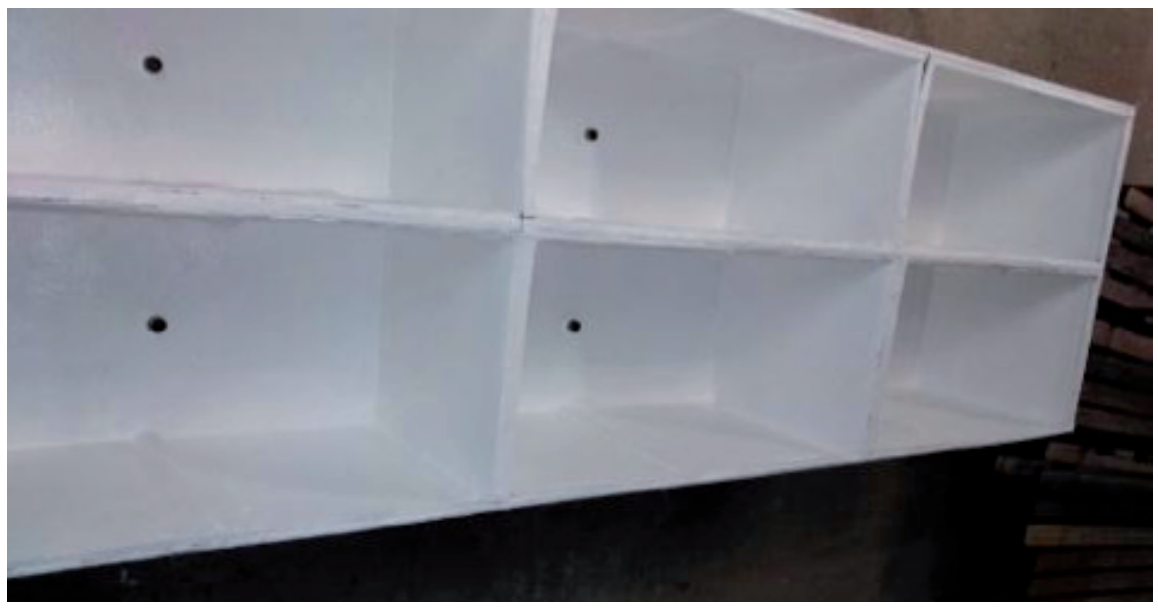

Source: Authors.

Later, fiberglass was used to create a structure with six fully watertight compartments, with more stability and resistance to support the different pressures to which the prototype will be subject.
Then the lids of the compartments are individually welded and a hole is made in each one of them to connect the valves responsible for injecting air into the structure.

Fig. 5. Top lid welding.

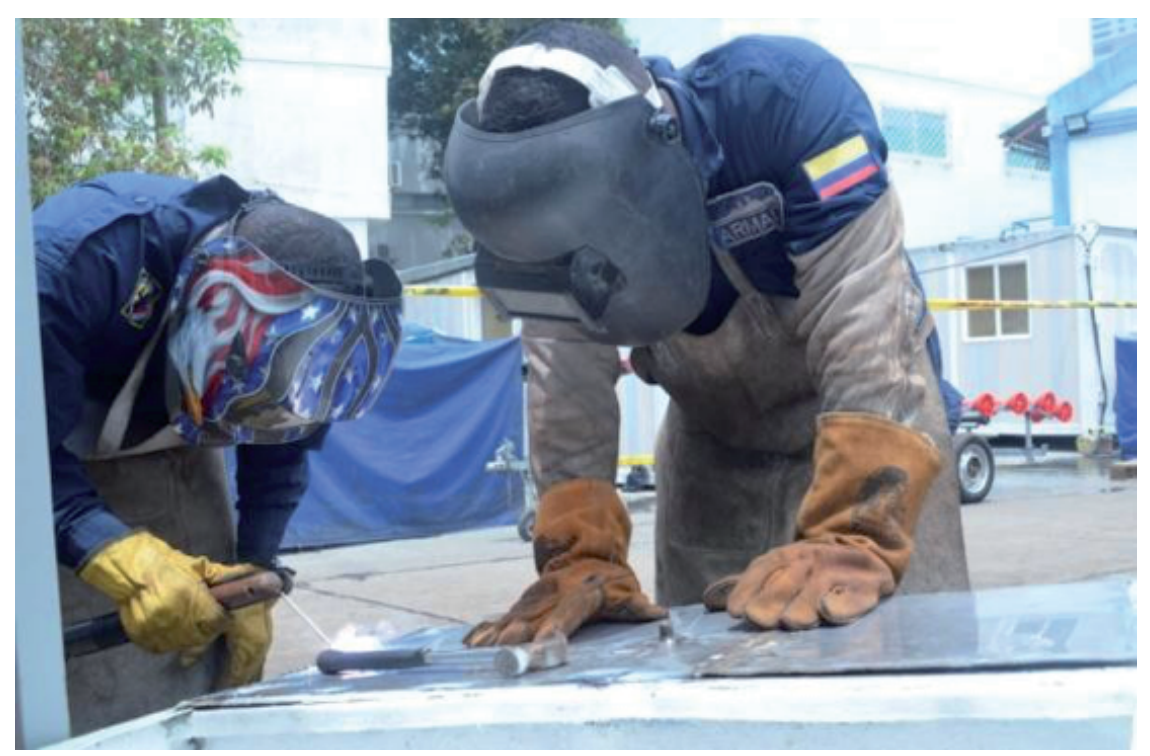

Source: Authors.

Bronze check valves were acquired, which are suitable for performing salvage maneuvers in the bongo. The holes opened in the upper lids were used to place the butterfly anchors used as pressure plugs to allow air to escape when the compartments are flooded with water.
Finally, a mechanical routine was carried out and then antifouling paint was applied on the hull, which is a special paint for the protection of the hull due to its ability to stop the development and expansion of living marine organisms that may compromise the performance, the seaworthy 
conditions of the structure and the durability of materials and components submerged in the ocean, thus providing a barrier to stop corrosion in metal hulls.

Fig. 6. Butterfly anchors.

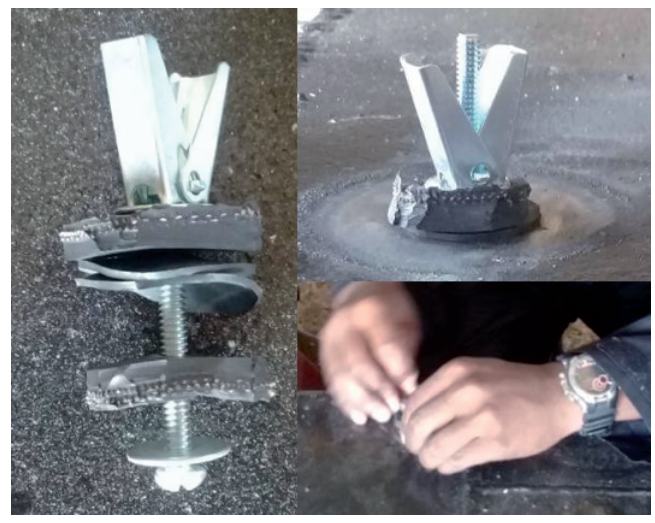

Fig. 7. Application of antifouling paint.

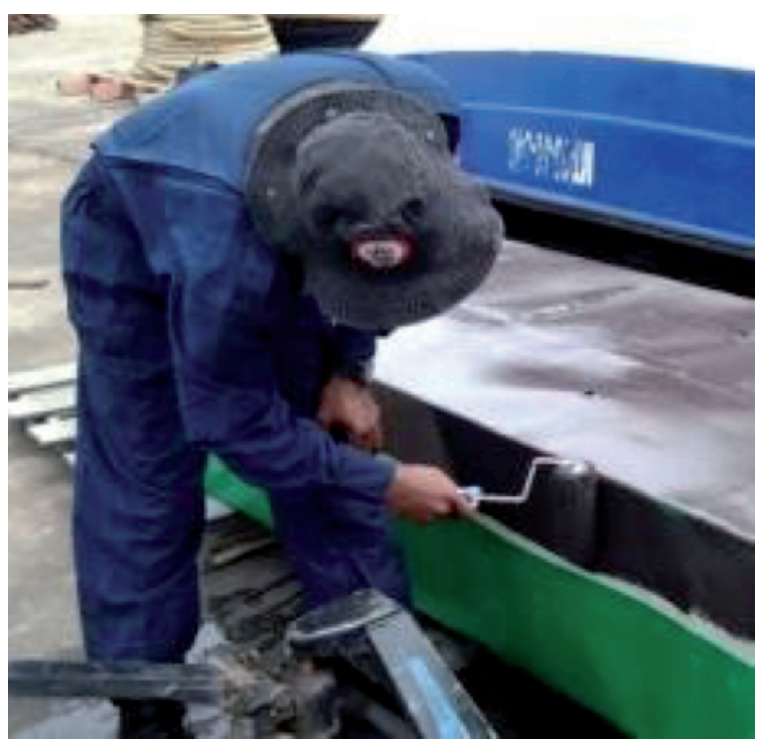

Fig. 8. Final Prototype.

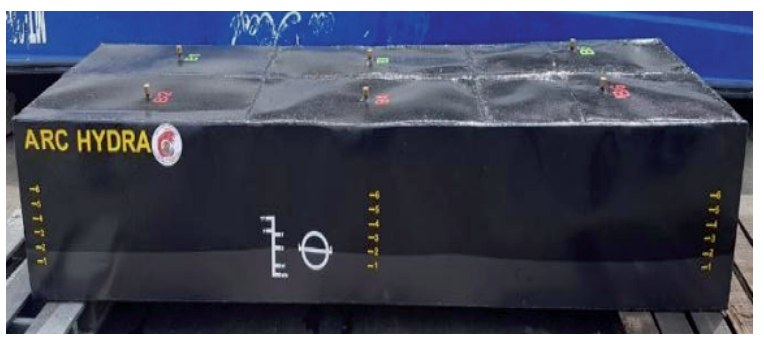

Source: Authors.

\section{Step 3: DESIGN THE MODEL OF THE PROTOTYPE BONGO}

A pneumatic test was carried out to verify the airtightness of each of the watertight compartments and to check the operation of the non-return valves located in the lower part of the prototype. To achieve this, a low pressure compressor with a maximum pressure of 180 psi was required with its respective compressed air outlet hose at $60 \mathrm{psi}$, which is the pressure needed to overcome the resistance of each check valve on the surface, and these tests determined the correct operation of such check valves, evacuating the water lodged inside each compartment.

Fig. 9. Application of antifouling paint.

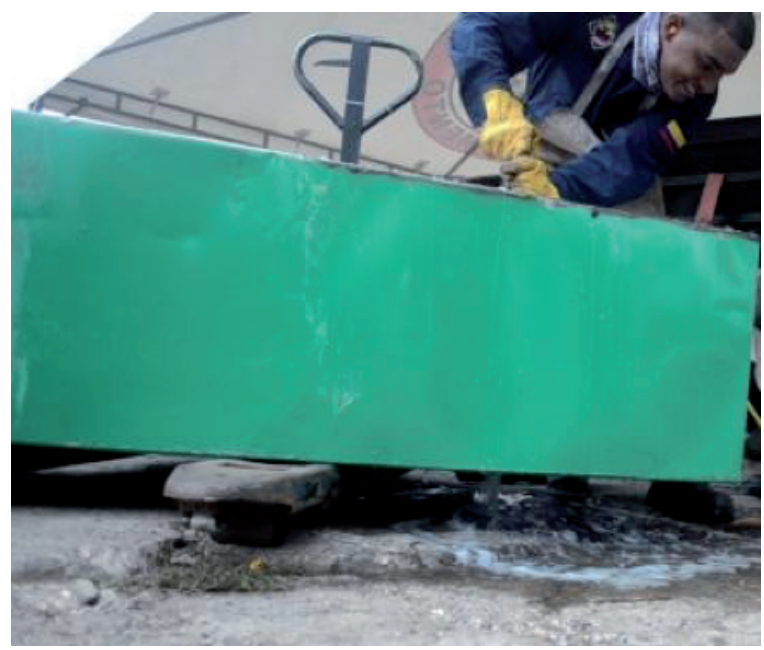

Source: Authors.

Then, the low pressure compressor setup was carried out, a hose 10 meters long was connected to the air outlet valve of the compressor, then the necessary equipment was assembled so that divers could carry out the refloat maneuver.

Then the prototype is placed in the water, keeping afloat, then the plugs are removed from the top to begin filling them with water, confirming the proper performance of the filling holes.

Once the simulator was at the bottom, 2 divers entered and proceeded to connect the compressor 
Fig. 10. 180 psi compressor.

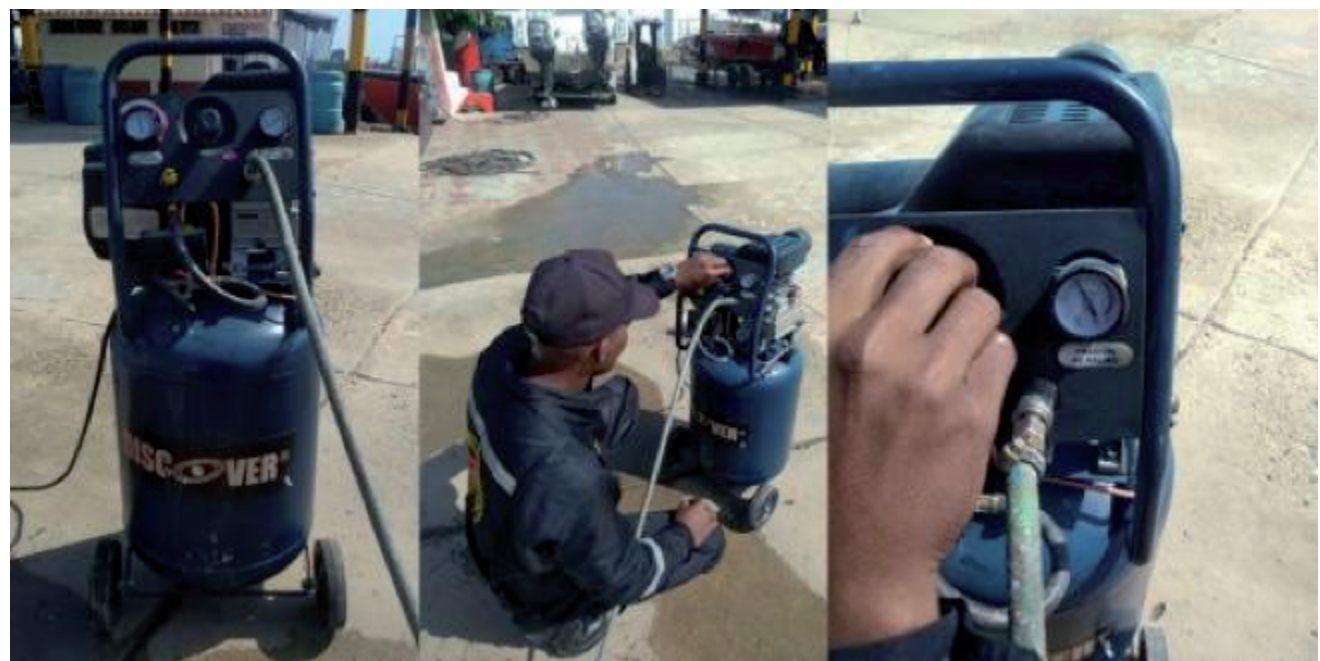

Source: Authors.

hose to one of the flooded compartments. The hose was pressurized to $70 \mathrm{psi}$ in order to inject compressed air and thus observe the behavior and conditions of the prototype as it begins to empty the water of each compartment.

The time to evacuate all the water from a compartment is calculated and recorded (4 minutes), its ascent speed increases as it approaches the surface, this is explained in Boyle's law regarding to the increase in air volume when the absolute pressure to which the simulator is subject decreases.

It is important to highlight that the pressure required is determined according to the direct observation of the behavior of the bongo in different conditions. According to this the compressor measurements table (see Table 2) was established indicating the proper use of the prototype starting from 15 feet and in an increasing pressure scale until achieving the maximum descent of 20 feet that is the depth of the dock at the Diving and Salvage School, in which the prototype is intended to be used during instruction days.

This exercise allowed demonstrating the successful refloating of the simulator following the instructions of the procedure.
Fig. 11. Filling water into the compartments of the Prototype.

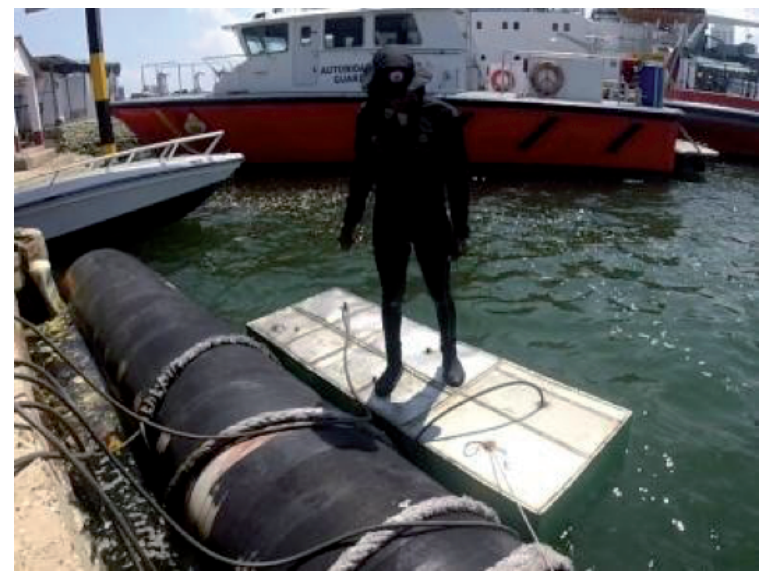

Source: Authors.

Fig. 12. Prototype submerged at 20 feet.

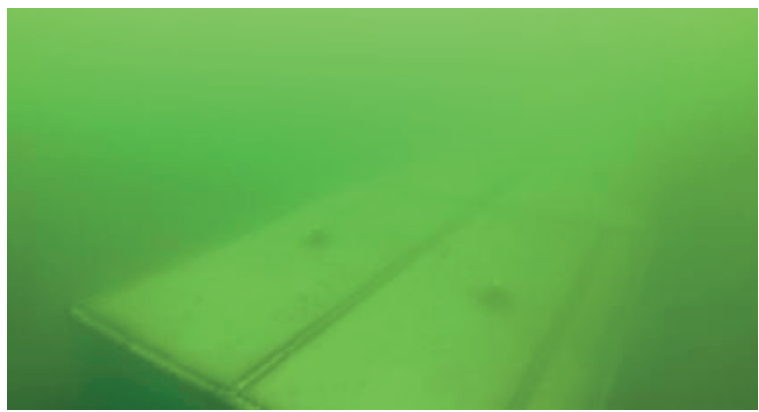

Source: Authors. 
Table 2. Constant pressure table for each foot of seawater.

\begin{tabular}{|c|c|c|c|}
\hline Depth in feet & Increase by Depth & Total & $\begin{array}{r}\text { Unit of } \\
\text { Measurement }\end{array}$ \\
\hline Surface & N/A & 60 & PSI \\
\hline 15 & 6.675 & 67 & PSI \\
\hline 20 & 8.9 & 69 & PSI \\
\hline 25 & 11.125 & 71 & PSI \\
\hline 30 & 13.35 & 73 & PSI \\
\hline $\begin{array}{l}\text { Constant per fo } \\
\text { increased }\end{array}$ & of seawater & 0.45 & PSI \\
\hline \multicolumn{4}{|c|}{ PSI (Pressure per Square Inch) } \\
\hline \multicolumn{4}{|c|}{ Increase by Depth $=$ Depth in feet $* 045$} \\
\hline
\end{tabular}

Source: Authors.

Fig. 13. Prototype reaching the surface in a controlled manner.

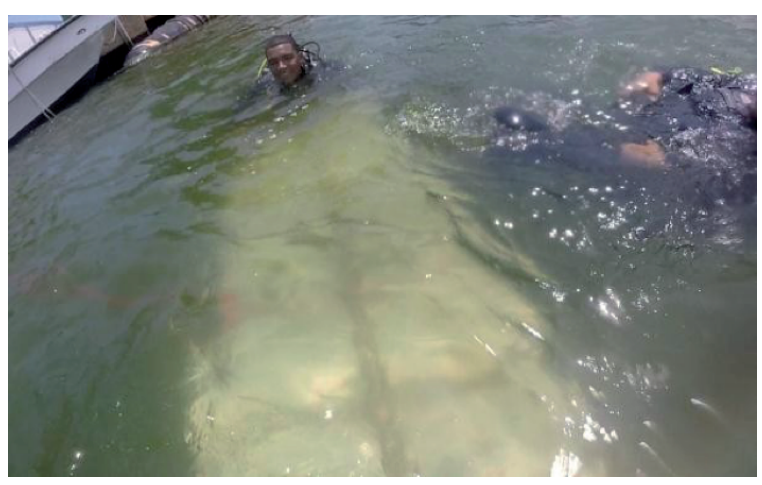

Source: Authors.

Fig. 13. Prototype reaching the surface in a controlled manner.

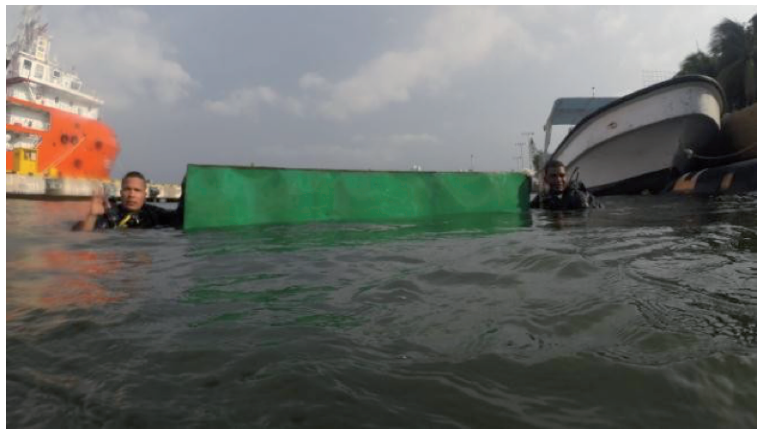

Source: Authors.
A manual in which the proper way to perform maneuvers with the prototype is determined is delivered together with the bongo simulator. It also describes the step-by-step maintenance required to preserve the structure in optimal conditions.

\section{Conclusions}

Once the investigation was completed and the analyzes of the data collected were carried out, refloat maneuvers were performed with the prototype bongo, from the moment in which the prototype is at the bottom of the sea until it has refloated back to the surface.

On the other hand, by making a detailed analysis of the salvage air system of the bongo ARC "CASA", it was possible to understand its structure and operation, which allowed determining the materials and tools necessary for the operation of the simulator that was later implemented in the instruction days in the Diving School of the Navy.

The studies and analyzes carried out on the materials and tools for the construction of the simulator allowed determining that stainless steel is the most suitable material, which adjusts to the shape and dimensions determined by the scale, confirming the previous calculations and ensuring 
the buoyancy of the structure with sufficient pushing force that serves as a support for the weight that was later added in the construction process of the simulator.

It is important to highlight the importance of caring for the structure as it is part of the training tools of the Naval School of NCOs. For this purpose, it is necessary to effectively use the checklist for the effective use of the simulator and also to follow the procedure guidelines, which instructions allow ensuring the optimal operation and development of various learning activities.

Finally, the reduction of costs with respect to the benefits of the project for the School was obvious, thus avoiding any possible damages to the bongo ARC "CASA" during salvaging instructions by using the prototype, in addition to the fact that the costs necessary to flood it are high and would require a greater amount of time and personnel to be achieved, and also because the cost of maintenance versus the maintenance of the prototype built is much higher.

\section{References}

[1] BRAVO RODRÍGUEZ, JOSÉ; ORTEGA CANTERO, MANUEL. Human-computer interaction systems. University of Castilla-La Mancha.2001.
[2] GIANCOLI, DOUGLAS. Physics: Principles with Applications. Sixth edition. Pearson Education. 2006.

[3] NEMBER SARAY. Analysis of the current situation in the refloating of sunken vessels. University of the Lagoon Polytechnic School of Engineering - Nautical, Machinery and Naval Radio Electronics Section July 2015.

[4] U.S NAVY SHIP. Salvage Manual. Submarine Salvage. Volume II. Washington D.C., 1970. P $6 \quad 12$ [Online] CdS. January 27, 2017. [Revised March 25, 2018]. Available online: http://www.cadenadesuministro.es/noticias/ conectando

[5 LÓPEZ, JORDI. U-history. The Ballast Tanks. OR HISTORY.COM [online]. [Revised March 12, 2107] Available online: https://www.uhistoria.com/uhistoria/te cnico/ articulos/lastre/lastre.htm.

[6 PEREZ JULIAN, MERINO MARIA: Concept of Pedagogy (https://definicion.de/pedagogia/) 2012.

[7] BROWN, THEODORE L.; LEMAY, $\mathrm{H}$. EUGENE, JR.; BURSTEN, BRUCE E. Chemistry. La Ciencia Central, 9th edition; Pearson Prentice-Hall: Mexico, 2004. 